\title{
LOCALIZATION OF L-GLUTAMATE RECEPTORS IN RAT BRAIN BY QUANTITATIVE AUTORADIOGRAPHY ${ }^{1}$
}

\author{
SHELLEY HALPAIN, ${ }^{*}$ CAROLINE M. WIECZOREK, $\ddagger$ AND THOMAS C. RAINBOW $\ddagger^{2}$ \\ *The Rockefeller University, New York, New York 10021 and $\ddagger$ Department of Pharmacology, Medical School, University of \\ Peninsylvania, Philadelphia, Pennsylvania 19104
}

Received December 19, 1983; Revised March 7, 1984; Accepted March 8, 1984

\begin{abstract}
In vitro autoradiography was used to characterize and quantitatively map the sodium-independent binding of $\left[{ }^{3} \mathrm{H}\right]$ glutamate in rat brain. Measured in the presence of chloride, glutamate binding to frozen brain sections was specific, saturable, and reversible, with a $K_{d}$ in the low micromolar range. At least two distinct binding sites were detected which had different affinities for quisqualic acid $(0.7 \mu \mathrm{M}$ and $1.2 \mathrm{~mm})$. Autoradiograms revealed very high levels of binding in rostral forebrain areas, especially olfactory structures and frontal cortex. High levels of binding were found in sensory cortex, certain hippocampal subfields, caudate, lateral septum, and other limbic structures. Lowest levels were seen in globus pallidus, preoptic area, brainstem reticular formation, and spinal trigeminal nucleus. All other regions, including midbrain, thalamus, hypothalamus, and cerebellar cortex exhibited moderate levels of $\left[{ }^{3} \mathrm{H}\right]$ glutamate binding. Within the hippocampus glutamate binding was greatest in the inner two-thirds of the dentate molecular layer, subiculum, and CA1 stratum radiatum. CA3 was much less densely labeled; CA2 and CA4 were intermediate. Unlike cell layers in the cerebellum, hippocampal pyramidal and granule cell layers appeared mostly devoid of binding. The relationship of these binding sites to putative glutamate receptor subclasses and glutamatergic pathways is discussed.
\end{abstract}

Since the first suggestion of its role in excitatory neurotransmission in the mammalian brain (Curtis and Watkins, 1960), numerous studies have been directed at elucidating the location and mechanism of glutamate interaction with CNS neurons. Studies of sodium-dependent uptake of acidic amino acids (Logan and Snyder, 1972), calcium-dependent release (Nadler et al., 1976), and synthesizing enzymes (Cotman and Hamberger, 1977; Wenthold, 1981) have been combined with lesion techniques to reveal several putative glutamate-using pathways (Fonnum and Malthe-Sorenssen, 1981). At the same time, both physiological (Davies and Watkins, 1983; Dingledine, 1983) and biochemical techniques (Foster and Roberts, 1978; Biziere et al., 1980; Baudry and Lynch, 1981; Michealis et al., 1981; Werling and Nadler, 1982) have been used in attempts to demonstrate that glutamate interacts with sites having the appropriate specificity expected of postsynaptic neurotransmitter receptors. Usually spinal cord, cerebellum, or hippocampus has been used as the model system for studying glutamate actions because these lamellar structures are more amenable to electrophysiological analysis and identification of specific pathways.

So far only gross dissection techniques combined with membrane-binding assays have been employed to define the distribution of specific interaction sites for glutamate as a neuro-

${ }^{1}$ This work was supported by National Institutes of Health Grants NS19597 and NS20006, and by Klingenstein and Sloan fellowships to T. C. R. S. H. is the recipient of an Albert Cass Traveling Fellowship. We thank J. Victor Nadler and Barry B. Wolfe for helpful discussions.

${ }^{2}$ To whom correspondence should be addressed. transmitter. It is difficult on the basis of these studies alone to determine what brain regions are rich in glutamate receptors and where, within a structure, the receptors are located. Substantial portions of white matter and glutamate receptor-sparse regions are inevitably included to varying degrees in such preparations. Recently, however, we described a method for localizing glutamate-binding sites throughout the brain (Halpain et al., 1983) using an adaptation of an in vitro autoradiographic technique (Young and Kuhar, 1979) which allows quantitation by densitometry (Quirion et al., 1981; Rainbow et al., 1982; Unnerstall et al., 1982; Pan et al., 1983). Other laboratories have also succeeded in applying this technique to studies of glutamate receptors (Greenamyre et al., 1983; Monaghan et al., 1983).

In the following report we present evidence that the glutamate-binding site labeled with $\left[{ }^{3} \mathrm{H}\right]$ glutamate by in vitro autoradiography resembles a physiological glutamate receptor; and furthermore, that at least two distinct populations of sites exist having different affinities for quisqualic acid. In addition, we have extensively mapped the location of $\left[{ }^{3} \mathrm{H}\right]$ glutamate binding to rat brain using quantitative densitometry.

\section{Materials and Methods}

Labeling of $\left[{ }^{3} \mathrm{H}\right]$ glutamate-binding sites in frozen brain sections. $\mathrm{Be}-$ fore localizing $\left[{ }^{3} \mathrm{H}\right.$ ]glutamate sites by autoradiography, we carefully characterized by scintillation counting the binding of $\left[{ }^{3} \mathrm{H}\right]$ glutamate to frozen brain sections. While our previous work (Halpain et al., 1983) had indicated that the site we labeled in frozen sections was generally similar to the chloride-dependent binding site observed in hippocampal membranes (Foster and Roberts, 1978; Baudry and Lynch, 1981; Wer- 
ling and Nadler, 1982), there are reports that this site is destroyed by freezing (Werling et al., 1983); therefore, we felt it was necessary to provide a detailed characterization of the properties of $\left[{ }^{3} \mathrm{H}\right]$ glutamate binding to slide-mounted sections.

For both scintillation counting and autoradiographic experiments, adult male CD rats (Charles River; 200 to $300 \mathrm{gm}$ ) were sacrificed by decapitation, and their brains were removed, mounted onto cryostat chucks, and frozen immediately in powdered dry ice. Thirty-two-micrometer thick coronal sections were cut from brains at $-15^{\circ} \mathrm{C}$ using an $\mathrm{A} / \mathrm{O}$ Reichart Histostat cryostat. The sections were thaw-mounted onto chromate/gelatin subbed microscope slides and were either used immediately or stored with desiccant at $-70^{\circ} \mathrm{C}$ for 1 to 7 days. For scintillation counting we used only sections through the rostral-caudal extent of the hippocampus. For autoradiography sections were cut in the plane of the stereotaxic atlas of Paxinos and Watson (1982), taking sections at roughly $500-\mu \mathrm{m}$ intervals. Consecutive sections were taken at each level for determination of total and nonspecific binding. After warming frozen sections to room temperature, a procedure that we find promotes adherence to slides, we pre-incubated sections in histological slide-jars containing $4^{\circ} \mathrm{C} 50 \mathrm{~mm}$ Tris- $\mathrm{HCl}$ buffer, $\mathrm{pH}$ 7.4. Two preincubations were used, each lasting $10 \mathrm{~min}$. In extensive preliminary experiments, we observed no specific binding in the absence of a preincubation, probably due to competition from endogenous glutamate or other endogenous inhibitors. Longer pre-incubations or pre-incubations at a higher temperature did not increase specific binding. After pre-incubations, the sections were allowed to dry at room temperature $\left(23\right.$ to $25^{\circ} \mathrm{C}$ ) and were covered with $300 \mu \mathrm{l}$ of $50 \mathrm{~mm}$ Tris-HCl buffer, $\mathrm{pH} 6.8$, containing $\left[{ }^{3} \mathrm{H}\right]-\mathrm{L}$-glutamate $(33$ or $50 \mathrm{Ci} / \mathrm{mmol}, \mathrm{ICN})$. For autoradiography sections were labeled with $300 \mathrm{nM}\left[{ }^{3} \mathrm{H}\right]$ glutamate. A concentration of $150 \mathrm{nM}\left[{ }^{3} \mathrm{H}\right]$ glutamate was used for scintillation counting studies. The sections were incubated at 23 to $25^{\circ} \mathrm{C}$ with the ligand for $1 \mathrm{hr}$, at which time binding had reached equilibrium (see Fig. $1 A$ ). Nonspecific binding was defined as the labeling in the presence of $1 \mathrm{mM}$ L-glutamate. In experiments to characterize the specificity of $\left[{ }^{3} \mathrm{H}\right]$ glutamate hinding, sections were co-incubated with a variety of compounds reported to interact with glutamate receptors. These compounds were obtained from Sigma Chemical Co. (St. Louis, MO), with the exception of $\alpha$-amino-3-hydroxy-5-methyl-4-isoxazolepropionic acid (AMPA), which was a gift from Dr. P. Krogsgaard-Larsen. After incubation the sections were rinsed of excess $\left[{ }^{3} \mathrm{H}\right]$ glutamate by two 5min washes in ice-cold Tris-HCl. In extensive preliminary experiments to determine wash times, we found no specific binding with wash times of two 30 -sec washes or two 1-min washes. Two 2 -min wash times revealed specific binding, but a poor ratio of total to nonspecific binding (1.5 to 1). Using two 5-min wash times, we lost 20 to $30 \%$ of the specific binding found with two 2-min wash times but obtained improved total/ nonspecific ratios, ranging from 2 to 3:1. Longer wash times caused greater loss of specific binding with no improvement in the percentage of specific binding. In experiments to test the chloride dependence of the binding, $50 \mathrm{mM}$ Tris/acetate buffer was substituted for Tris-HCl in all steps of the procedure.

Quantitative densitometry. After the two 5-min rinses, the sections were either removed with glass fiber filter disks and used for scintillation counting or were dried rapidly on a $60^{\circ} \mathrm{C}$ slide-warmer and applied against LKB Ultrofilm (LKB, Inc., Gaithersburg, MD) as described (Rainbow, A. Biegon, and D. Berck, 1982) to generate autoradiograms. Spring-loaded aluminum $\mathrm{x}$-ray film cassettes were used to assure a uniform apposition of film and brain sections. After 60 days' exposure at room temperature, the LKB film was developed in Kodak GBX developer for $3 \mathrm{~min}$ and fixed for $6 \mathrm{~min}$ in Kodak rapid fixer. Densitometric analysis of $\left[{ }^{3} \mathrm{H}\right]$ glutamate binding was performed as described previously (Rainbow et al., 1982; T. C. Rainbow, A. Biegon, and D. Berck, submitted for publication). Slide-mounted autoradiograms were magnified $\times 10$ with a histological slide projector, and the image was maneuvered over a photocell $100 \mu \mathrm{m}$ in diameter. The photocell was connected to an Atari 800 microcomputer, which converted density values into molar quantities of bound ligand by referencing a tritium brain-mash standard curve (Unnerstall et al., 1982; T. C. Rainbow, A. Biegon, and D. Berck, submitted for publication). These standards are calibrated for the tritium concentration in gray matter structures and underestimate the concentration of radioactivity in white matter structures (Alexander et al., 1981; T. C. Rainbow, A. Biegon, and D. Berck, submitted for publication). Values for total and nonspecific $\left[{ }^{3} \mathrm{H}\right]$ glutamate bound were obtained for each region from an animal by averaging 8 to 10 readings over an area. Equal numbers of readings were taken bilaterally and averaged together.
Analysis of competition data. Competition curves constructed from scintillation counting or densitometric data were analyzed using a nonlinear least-squares method via the computer program FITSITES on the National Institutes of Health-supported PROPHET network. The untransformed data were tested for homology with one, two, and three separate binding site models, and $F$ test analysis was used to determine the most appropriate fit. The program yielded estimates of the densities of the separate binding sites and of the affinities of each site for competing compounds.

\section{Results}

Properties of $\left[{ }^{3} \mathrm{H}\right]$ glutamate binding to frozen brain sections. Liquid scintillation counting experiments indicated that the binding of $\left[{ }^{3} \mathrm{H}\right]$ glutamate to frozen sections was saturable, reversible, and showed a speciticity in general agreement with the properties of $\left[{ }^{3} \mathrm{H}\right]$ glutamate-binding sites found in mammalian CNS membrane preparations (Foster and Roberts, 1978; Baudry and Lynch, 1981; Werling and Nadler, 1982). Experiments in which the incubation was allowed to proceed for various times showed the binding to reach equilibrium at room temperature in approximately $35 \mathrm{~min}$ and to remain stable for at least $60 \mathrm{~min}$ (Fig. $1 A$ ). This binding is reversible, as shown in Figure $1 B$. After a 60 -min incubation the binding was stopped by "infinite" dilution in a 100 -fold excess of cold Tris buffer for various times before continuing with the normal procedure of two 5-min washes. Calculation of on- and off-rates from these data yielded a $k_{+1}$ of $0.0034 \mu \mathrm{M}^{-1} \mathrm{~min}^{-1}$ (secondorder rate equation) and $k_{-1}$ of $0.6 \mathrm{~min}^{-1}$. These numbers probably reflect not only the kinetics of the interaction of the ligand with the binding site, but also the penetration of $\left[{ }^{3} \mathrm{H}\right]$ glutamate through the $32-\mu \mathrm{m}$ tissue section. The estimated $K_{d}$ from the ratio of $k_{-1} / k_{+1}$ was $176 \mu \mathrm{M}$. Figure $1 C$ shows a representative saturation curve of $\left[{ }^{3} \mathrm{H}\right]$ glutamate binding, using dilution with unlabeled glutamate to obtain saturating concentrations. Prelininary Scatchard analyses of $\left[{ }^{3} \mathrm{H}\right]$ glutamate binding produced a $K_{d}$ value of $0.7 \mu \mathrm{M}$ (Halpain et al, 1983); however, in these studies only a few concentrations of Lglutamate were used. Given the potential problems in interpreting such limited Scatchard plots (Klotz, 1982), we repeated these studies using a larger range of concentrations $\left(10^{-9}\right.$ to $\left.10^{-3} \mathrm{M}\right)$. Linear least squares estimates gave a $K_{d}$ of $57.5 \pm 5$ $\mu \mathrm{M}$ and $\mathrm{a} B_{\max }$ of $18.6 \pm 3.6 \mathrm{pmol} / \mathrm{mg}$ of protein $(N=7)$. Computerized nonlinear least squares analysis showed the data to fit a two-site binding model much better than a one-site model ( $p<0.0001$ for improvement in the $F$ value), with $I C_{50}$ values of $3.4 \mu \mathrm{M}$ and $227 \mu \mathrm{M}$ for the two sites and relative $B_{\max }$ values of 60:40. The site with the affinity in the low micromolar range would roughly correspond to the $K_{d}$ for $\left[{ }^{3} \mathrm{H}\right]$ glutamate binding observed in membrane studies (e.g., Werling and Nadler, 1982), while the site with the high micromolar affinity may represent a novel $\left[{ }^{3} \mathrm{H}\right]$ glutamate-binding site. Using a concentration of $300 \mathrm{~nm}\left[{ }^{3} \mathrm{H}\right.$ ]glutamate for autoradiography, $99 \%$ of the specific binding is to the high affinity site and $1 \%$ to the low affinity site.

Table I gives the relative potencies of a variety of putative glutamate receptor agonists and antagonists in competing for $\left[{ }^{3} \mathrm{H}\right]$ glutamate binding to frozen sections. After L-glutamate itself, the excitant quisqualic acid was the most potent inhibitor of $\left[{ }^{3} \mathrm{H}\right]$ glutamate binding, showing strong evidence for biphasic inhibition (Fig. 2). Computer analysis of competition curves indicated a significant improvement $(p<0.0001)$ in fit to a two-site binding model, with $\mathrm{IC}_{50}$ values of roughly $500 \mathrm{~nm}$ and $1 \mathrm{mM}$, and the high affinity site accounted for $60 \%$ of the total binding. Biphasic inhibition of $\left[{ }^{3} \mathrm{H}\right]$ glutamate binding by quisqualate has been observed in membrane studies (Werling and Nadler, 1982; Fagg et al., 1983; Werling et al., 1983). In preliminary experiments, we obtained similar estimates of $\mathrm{IC}_{50}$ values and percentage capacities when quisqualate competition curves were constructed from densitometric data. Next in potency to 


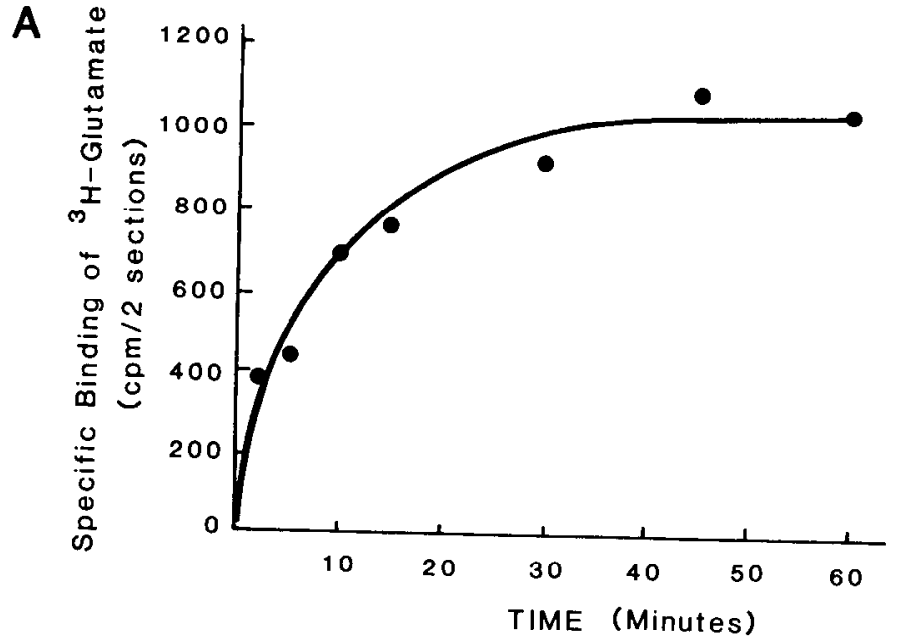

B

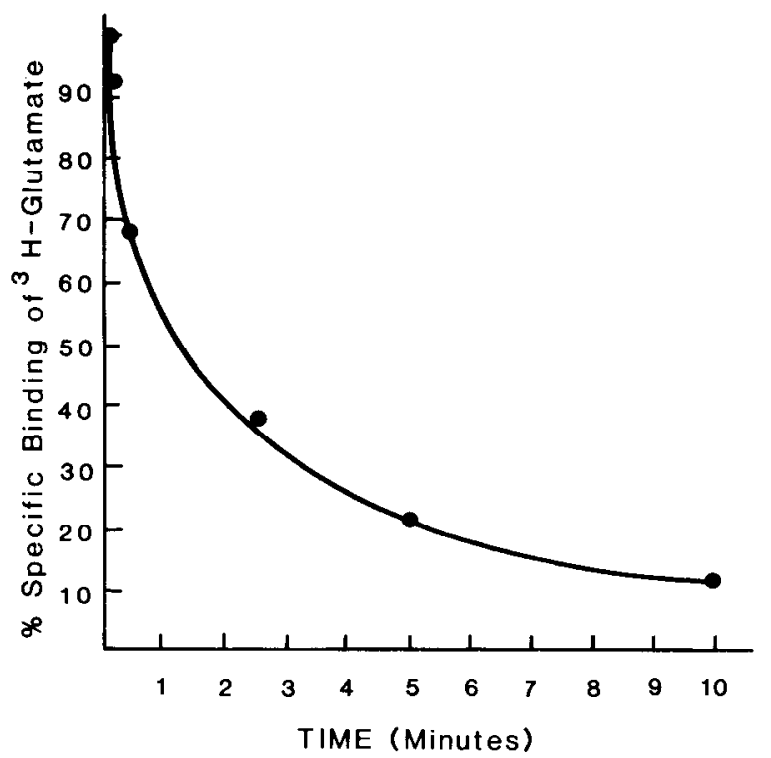

C

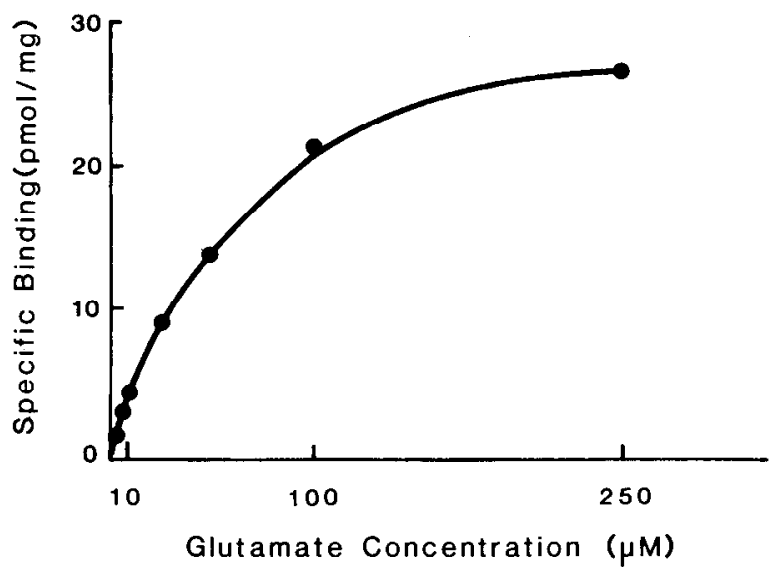

Figure 1. A, Equilibrium time course of $\left[{ }^{3} \mathrm{H}\right]$ glutamate binding. Binding of $150 \mathrm{nM}\left[{ }^{3} \mathrm{H}\right]$ glutamate was performed as described, and the incubation was allowed to proceed for various times before the binding was stopped by immersion in cold Tris buffer for two 5 -min rinses. The curve represents data averaged from three experiments. $B$, Reversibility of $\left[{ }^{3} \mathrm{H}\right]$ glutamate binding. The glutamate-binding procedure was carried out as described. After incubation for $1 \mathrm{hr}$ with $150 \mathrm{nM}\left[{ }^{3} \mathrm{H}\right]$ glutamate, quisqualate were the powerful excitants ibotenate and homocysteate, with $\mathrm{IC}_{50}$ values of about $200 \mu \mathrm{M}$ and $300 \mu \mathrm{M}$, respectively. L-Aspartate and $\mathrm{L}-\alpha$-aminoadipate were of intermediate potency $\left(\mathrm{IC}_{50}\right.$ values $=700 \mu \mathrm{M}$ and $2000 \mu \mathrm{M}$, respectively). None of these competitors showed a significant improvement in fit when competition curves were analyzed to a two-site binding model. Neither kainic acid, $N$-methyl-D,L-aspartate, nor the putative quisqualate receptor agonist AMPA (Krogsgaard-Larsen et al., 1980) competed significantly for $\left[{ }^{3} \mathrm{H}\right]$ glutamate binding. There was a high degree of stereoselectivity for both glutamate and aspartate, the D-isomer of these compounds showing inhibition of binding only at very high concentrations. Of the three putative glutamate antagonists tested, D,L-amino4-phosphonobutyrate (APB) was the most potent competitor of glutamate binding, having an $\mathrm{IC}_{50}(800 \mu \mathrm{M})$ similar to $\mathrm{L}$ aspartate. Glutamate diethyl ester (GDEE) competed much less potently $\left(\mathrm{IC}_{50}=3.1 \mathrm{~mm}\right)$, and $\mathrm{D}-\alpha$-aminoadipate showed inhibition only at high concentrations.

The biphasic inhibition of $\left[{ }^{3} \mathrm{H}\right]$ glutamate binding by quisqualate and the rank order potency of the other competitors suggested that the properties of $\left[{ }^{3} \mathrm{H}\right]$ glutamate binding to frozen sections might best be explained by the classification scheme of Werling and Nadler $(1982,1983)$ and Werling et al. (1983). They have described two binding sites for $\left[{ }^{3} \mathrm{H}\right]$ glutamate in membranes, distinguishable by their different affinities for quisqualate. These two sites are designated "Glu A" (high affinity for quisqualate) and "Glu B" (low affinity for quisqualate). Recently, these investigators reported that the Glu A site is highly dependent on the presence of chloride (Werling and Nadler, 1983). To determine if $\left[{ }^{3} \mathrm{H}\right]$ glutamate binding to frozen sections corresponded to Glu A and Glu B divisions, inhibition studies were performed with quisqualate in the absence of chloride. In separate experiments, we determined that the binding of $\left[{ }^{3} \mathrm{H}\right]$ glutamate to frozen sections was stimulated by chloride, showing a 2 -fold decrease in binding when assays were performed in Tris/acetate $(19.0 \pm 2.4 \mathrm{fmol} / \mathrm{mg}$ of protein versus $43.8 \pm 3.8 \mathrm{fmol} / \mathrm{Ing}$ of protein, $N=4$ ). Computerized analysis of quisqualate inhibition curves in the absence of chloride (Fig. $2 B$ ) indicated that there was a marked reduction in the relative $B_{\max }$ of the high affinity site, dropping from $60 \%$ of the total binding to $30 \%$. There was also less overall competition by quisqualate, since at the highest concentration used, $1 \mathrm{~mm}$, there was $40 \%$ residual binding in the absence of chloride as compared to $20 \%$ residual in the presence of chloride. Both findings are consistent with the high affinity quisqualate site in frozen sections corresponding to the Glu A site. However, even in the absence of chloride, the curve was still biphasic, with the $\mathrm{IC}_{50}$ values similar to those found in the presence of chloride. This result may suggest that, in addition to Glu $A$ and Glu B sites, $\left[{ }^{3} \mathrm{H}\right]$ glutamate in frozen sections binds to a third site that shows a high affinity for quisqualate but is not dependent on chloride.

Anatomical distribution of $\left[{ }^{3} H\right]$ glutamate-binding sites. Table II provides a list of anatomical structures analyzed for $\left[{ }^{3} \mathrm{H}\right]$ glutamate binding by quantitative densitometry. For simplicity the forebrain structures, which contain the highest levels of binding, have been subdivided according to whether they fall

the binding was stopped by infinite dilution in an excess of cold Tris buffer for various times before the usual rinse procedure was employed (two 5-min washes). The curve represents the mean of three experiments. $C$, Saturability of $\left[{ }^{3} \mathrm{H}\right]$ glutamate binding to whole brain sections. Thirty-two-micrometer thick sections were prepared, and the assay was conducted as described in the text. Various concentrations of unlabeled L-glutamate were included in the 1 -hr incubation with 150 nM $\left[{ }^{3} \mathrm{H}\right]$ glutamate. Specific binding of glutamate at each concentration was measured by liquid scintillation counting and fit to a hyperbolic curve by computer analysis. This curve represents data from a single experiment which was typical of our results. 
TABLE I

Relative potency of glutamate analogues in competing for $\left[{ }^{3} \mathrm{H}\right]$ glutamate binding to rat brain sections

Relative potency of glutamate analogues in inhibiting $\left[{ }^{3} \mathrm{H}\right]$ glutamate binding to rat brain frozen sections. Several concentrations of glutamate analogues were included in the incubation with $150 \mathrm{nM}\left[{ }^{3} \mathrm{H}\right]$ glutamate and glutamate binding assayed by scintillation counting as described in the text. Competition curves were analyzed with the FITSITES program for fit to one-, two-, and three-site binding models. Only L-glutamate and quisqualate produced any inhibition curves which fit a two-site model better than a one-site model. None gave improved fit to a three-site model.

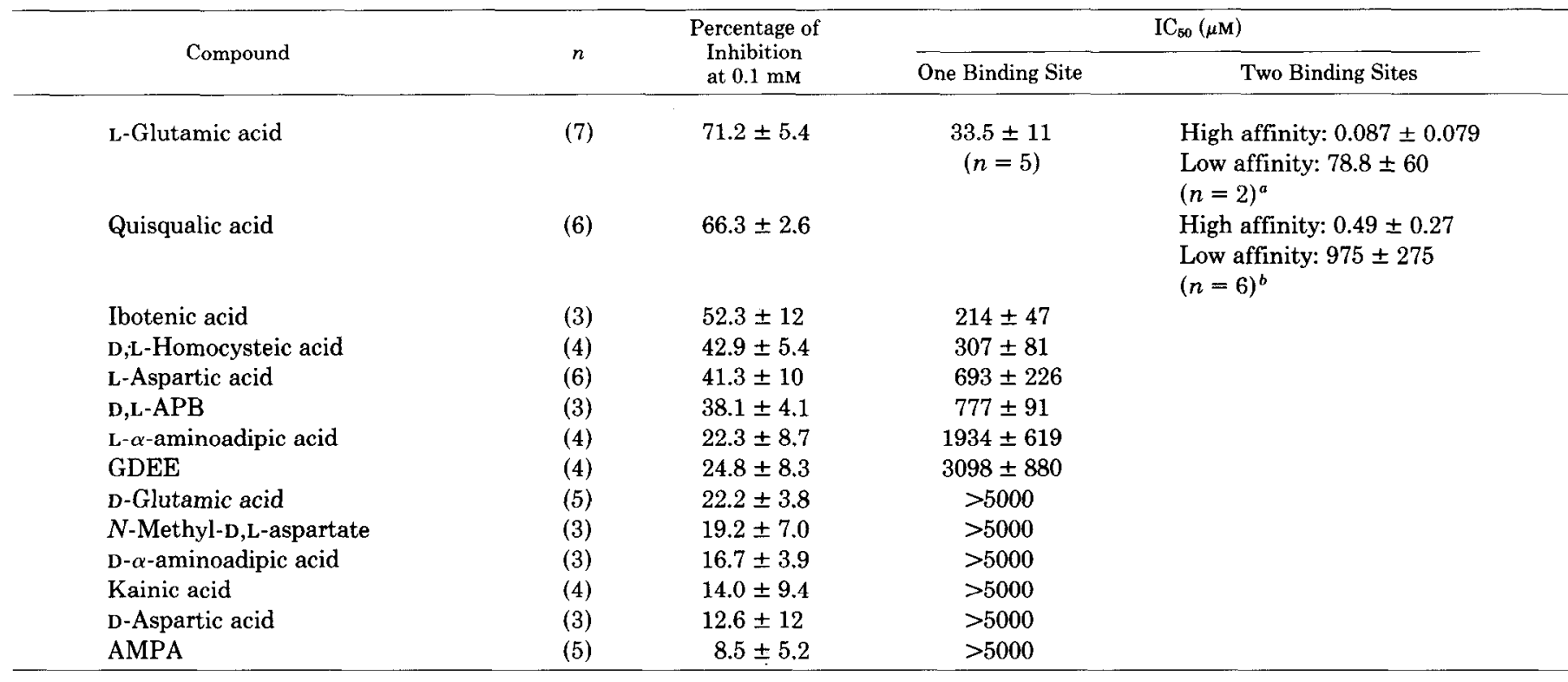

${ }^{a}$ Two of the seven individual competition curves for L-glutamate were biphasic; hence the two groups were analyzed separately.

${ }^{b}$ All six quisqualate inhibition curves fit a two-site binding model better than a one-site model. All improvements in fit were significant at $p<0.03$ or better. See Figure $2 A$ for the results of pooling these data.

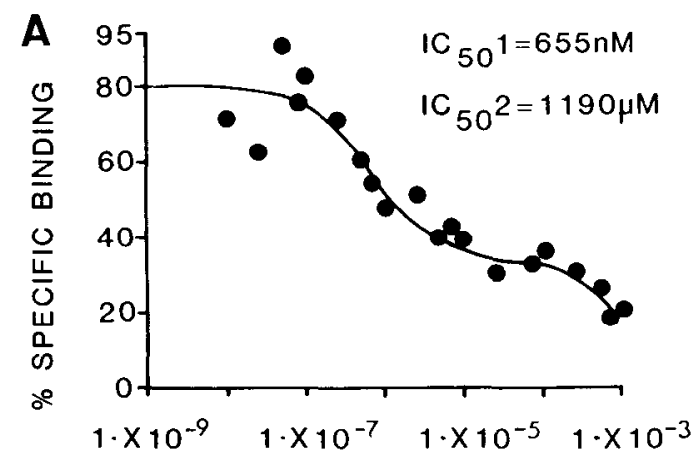

QUISQUALATE CONCENTRATION (M)

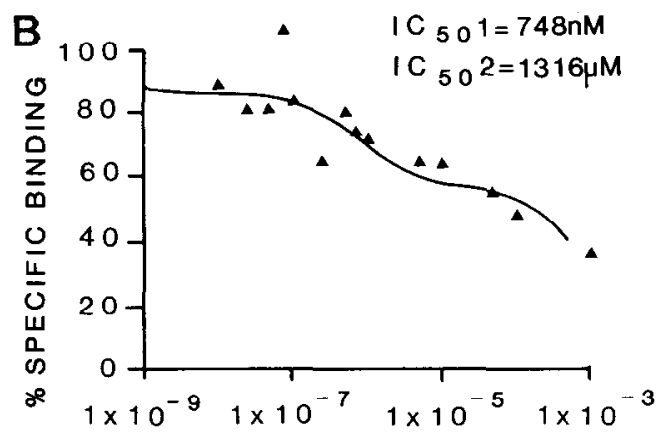

QUISQUALATE CONCENTRATION (M) in the very rostral, intermediate, or more caudal portions of the brain. Therefore, some structures are listed twice, because the level of $\left[{ }^{3} \mathrm{H}\right]$ glutamate binding showed rostral-caudal variation. Figure 3 represents a summary of these data, showing a sagittal section with typical average binding values in femtomoles per milligram of protein indicated for various anatomical regions.

The most interesting feature we noted is the striking rostralcaudal gradient of labeling through the forebrain (Figs. 3 and $4, A$ to $G$ ). Anterior forebrain areas, especially neocortex, caudate, and olfactory/limbic areas, are very heavily labeled with $\left[{ }^{3} \mathbf{H}\right]$ glutamate, and the labeling is seen to diminish gradually in more medial portions of these structures and then to become somewhat darker again toward the most caudal regions of forebrain. For example, layer I of cortical area 10, as defined

Figure 2. Inhibition of $\left[{ }^{3} \mathrm{H}\right]$ glutamate binding by quisqualic acid. Sections were prepared as described in the text. Various concentrations of quisqualic acid were included in the incubation with $150 \mathrm{nM}\left[{ }^{3} \mathrm{H}\right]$ glutamate, and specific binding was assayed by scintillation counting of sections wiped from the slides with glass fiber filter disks. Competition curves were analyzed by an iterative least squares curve fitting program. $A$, Average of six experiments performed in $50 \mathrm{mM}$ Tris-HCl, $\mathrm{pH}$ 6.8. The curve showed a significant improvement in fitting to a two-binding site model $(p<0.0001)$. The $\mathrm{IC}_{50}$ values for the two sites are given in the figure. The relative percentages of each site in this averaged curve were $58 \%$ for the high affinity site and $42 \%$ for the low affinity site. $B$, Average of four experiments performed in $50 \mathrm{mM}$ Tris acetate buffer, $\mathrm{pH}$ 6.8. This curve also showed a significant fit to two sites $(p<0.006)$, with the $\mathrm{IC}_{\tilde{5} 0}$ values being similar to those obtained in the presence of chloride $(A)$. The relative percentages of each site in this figure were $33 \%$ for the high affinity site and $67 \%$ for the low affinity site. 
TABLE II

Distribution of $\left[{ }^{3} \mathrm{H}\right]$ glutamate-binding sites in rat brain

The table shows the concentration of $\left[{ }^{3} \mathrm{H}\right]$ glutamate-binding sites among brain regions as determined by quantitative autoradiography. Frozen $32-\mu \mathrm{m}$ thick brain sections were labeled as described in the text with $300 \mathrm{nM}\left[{ }^{3} \mathrm{H}\right]$ glutamate and apposed to LKB Ultrofilm for 60 days to generate autoradiograms. Nonspecific binding was defined as the labeling in the presence of $1 \mathrm{~mm}$ L-glutamate and was subtracted from all readings. Brain sections were taken at $500-\mu \mathrm{m}$ intervals, corresponding to coronal levels of the stereotaxic atlas of Paxinos and Watson (1982). Serially cut sections at each level were used for determination of total and nonspecific binding. From 8 to 10 densitometric readings were taken from a single brain structure on an individual autoradiogran. Densitometric readings were converted into molar levels of $\left[{ }^{3} \mathrm{H}\right]$

\begin{tabular}{|c|c|c|c|}
\hline Brain Region & $\begin{array}{c}\text { Femtomoles per Milligram } \\
\text { of Protein }\end{array}$ & Brain Region & $\begin{array}{c}\text { Femtomoles per Milligram } \\
\text { of Protein }\end{array}$ \\
\hline Rostral forebrain & & Arcuate nucleus & $101 \pm 5$ \\
\hline Area 10 , layer 1 & $434 \pm 10$ & Ventromedial hypothalamic nucleus & $99 \pm 11$ \\
\hline Area 10 , layer 5 & $361 \pm 18$ & Medial forebrain bundle & $107 \pm 37$ \\
\hline Anterior olfactory nucleus & $363 \pm 14$ & Globus pallidus & $64 \pm 11$ \\
\hline Nucleus accumbens & $366 \pm 55$ & Medial preoptic nucleus & $47 \pm 22$ \\
\hline Pyriform cortex & $354 \pm 52$ & Lateral preoptic nucleus & $43 \pm 8$ \\
\hline Cingulate cortex & $366 \pm 17$ & Caudal forebrain/midbrain & \\
\hline Claustrum & $345 \pm 86$ & Dentate gyrus, molecular layer & $244 \pm 27$ \\
\hline Caudate, ventral ${ }^{a}$ & $390 \pm 9$ & Hilus & $191 \pm 13$ \\
\hline Caudate, dorsal ${ }^{b}$ & $284 \pm 13$ & CA4 & $210 \pm 50$ \\
\hline Lateral septum & $304 \pm 52$ & CA3, stratum oriens & $154 \pm 14$ \\
\hline Medial septum & $232 \pm 48$ & CA3, stratum radiatum & $182 \pm 26$ \\
\hline Olfactory tubercle & $302 \pm 52$ & CA2, stratum oriens & $190 \pm 28$ \\
\hline Nucleus of diagonal band & $198 \pm 49$ & CA2, stratum radiatum & $223 \pm 31$ \\
\hline Area 2, layer 1 & $317 \pm 17$ & CA1, stratum oriens & $221 \pm 37$ \\
\hline Area 2, layer 5 & $244 \pm 14$ & $\mathrm{CA1}$, stratum radiatum & $254 \pm 41$ \\
\hline Medial forebrain & & Subiculum & $252 \pm 10$ \\
\hline Caudate, ventral ${ }^{a}$ & $204 \pm 12$ & Posteriomedial cortical nucleus amygdala & $236 \pm 86$ \\
\hline Caudate, dorsal ${ }^{b}$ & $149 \pm 20$ & Central thalamic nucleus & $199 \pm 30$ \\
\hline Cingulate cortex & $243 \pm 27$ & Interpeduncular nucleus & $192 \pm 36$ \\
\hline Pyriform cortex & $237 \pm 53$ & Areas 17 and 18 & $177 \pm 22$ \\
\hline Area 2 , layers 1 and 2 & $200 \pm 13$ & Lateral posterior thalamic nucleus & $144 \pm 19$ \\
\hline Area 2, layer 5 & $147 \pm 19$ & Posterior thalamic nucleus & $136 \pm 18$ \\
\hline Olfactory tubercle & $185 \pm 50$ & Ventroposterior thalamic nucleus & $126 \pm 23$ \\
\hline Nucleus stria terminalis & $183 \pm 53$ & Lateral geniculate nucleus, dorsal & $130 \pm 20$ \\
\hline Lateral septum & $149 \pm 25$ & Central gray & $138 \pm 16$ \\
\hline Medial septum & $84 \pm 25$ & Superior colliculus, superficial layer & $124 \pm 25$ \\
\hline Basolateral amygdaloid nucleus & $217 \pm 47$ & Substantia nigra, pars reticularis & $71 \pm 12$ \\
\hline Medial amygdaloid nucleus & $171 \pm 37$ & Red nucleus & $65 \pm 17$ \\
\hline Central amygdaloid nucleus & $171 \pm 49$ & Cerebellum/medulla & \\
\hline Mediodorsal thalamic nucleus & $178 \pm 20$ & Dorsal cochlear nucleus & $197 \pm 19$ \\
\hline Anterodorsal thalamic nucleus & $154 \pm 18$ & Molecular layer, cerebellum & $165 \pm 19$ \\
\hline Laterodorsal thalamic nucleus & $135 \pm 27$ & Purkinje/granule cell layer & $160 \pm 17$ \\
\hline Anteroventral thalamic nucleus & $116 \pm 14$ & Medial vestibular nucleus & $82 \pm 31$ \\
\hline Ventrolateral thalamic nucleus & $101 \pm 19$ & Brainstem reticular nucleus & $50 \pm 22$ \\
\hline Anterior hypothalamic nucleus & $133 \pm 31$ & Spinal trigeminal nucleus & $29 \pm 31$ \\
\hline
\end{tabular}

a "Ventral" caudate refers to the most ventral third.

$b$ "Dorsal" caudate to a region dorsal to this that makes up roughly $70 \%$ of the total area of the caudate.

by Krieg (1946), showed specific binding of $434 \mathrm{fmol} / \mathrm{mg}$ of protein; layer $\mathrm{V}$ of area $10 \mathrm{had} 361 \mathrm{fmol} / \mathrm{mg}$ of protein. Layers $\mathrm{I}$ and $\mathrm{V}$ of area $2 \mathrm{had} 317 \mathrm{fmol} / \mathrm{mg}$ of protein and $244 \mathrm{fmol} / \mathrm{mg}$ of protein, respectively. This represents a $30 \%$ decline in glutamate binding from the more rostral area 10 to the more caudal area 2.

Similarly, area 2 itself becomes less densely labeled as it extends into the more intermediate portions of forebrain (Fig. $4, B$ to $D$ ). At its most caudal levels it becomes somewhat more heavily labeled. At a coronal level corresponding to Paxinos glutamate binding by reference to a tritium brain-mash standard curve (Unnerstall et al., 1982; T. C. Rainbow, A. Biegon, and D. Berck, submitted for publication). Values are means \pm SEM of femtomoles of $\left[{ }^{3} \mathrm{H}\right]$-L-glutamate specifically bound per milligram of protein, from readings taken from three rats. We averaged values over four rostralcaudal regions of rat brain, as little anterior-posterior variation in $\left[{ }^{3} \mathrm{H}\right]$ glutamate binding was observed across these coronal levels. "Rostral forebrain" corresponds to plates 9 to 13 in the Paxinos and Watson (1982) stereotaxic atlas, "medial forebrain" to the structures on plates 14 to 18 , "caudal forebrain/midbrain" to plates 19 to 26 , "cerebellum/ medulla" to coronal levels 39 and 40.

and Watson's (1982) Figure 11 (PW11; Fig. $4 B$ ) $\left[{ }^{3} \mathrm{H}\right]$ glutamate binding in layer $\mathrm{V}$ of area 2 measured $247 \mathrm{fmol} / \mathrm{mg}$ of protein. At PW14 it was $147 \mathrm{fmol} / \mathrm{mg}$ of protein, at PW16 it was 136 $\mathrm{fmol} / \mathrm{mg}$ of protein, and at PW18 (Fig. $4 D$ ) it was $199 \mathrm{fmol} /$ $\mathrm{mg}$ of protein. (Each PW level is $500 \mu \mathrm{m}$ apart; therefore, PW14 is $1 \mathrm{~mm}$ from PW16 in the rostral-caudal direction.)

Binding throughout the caudate-putamen appeared "patchy" (Fig. $4 B$ ), but these patches were below the resolving power of the photocell; therefore, measurements were averaged over a large area of caudate on each section. The ventral third of the 


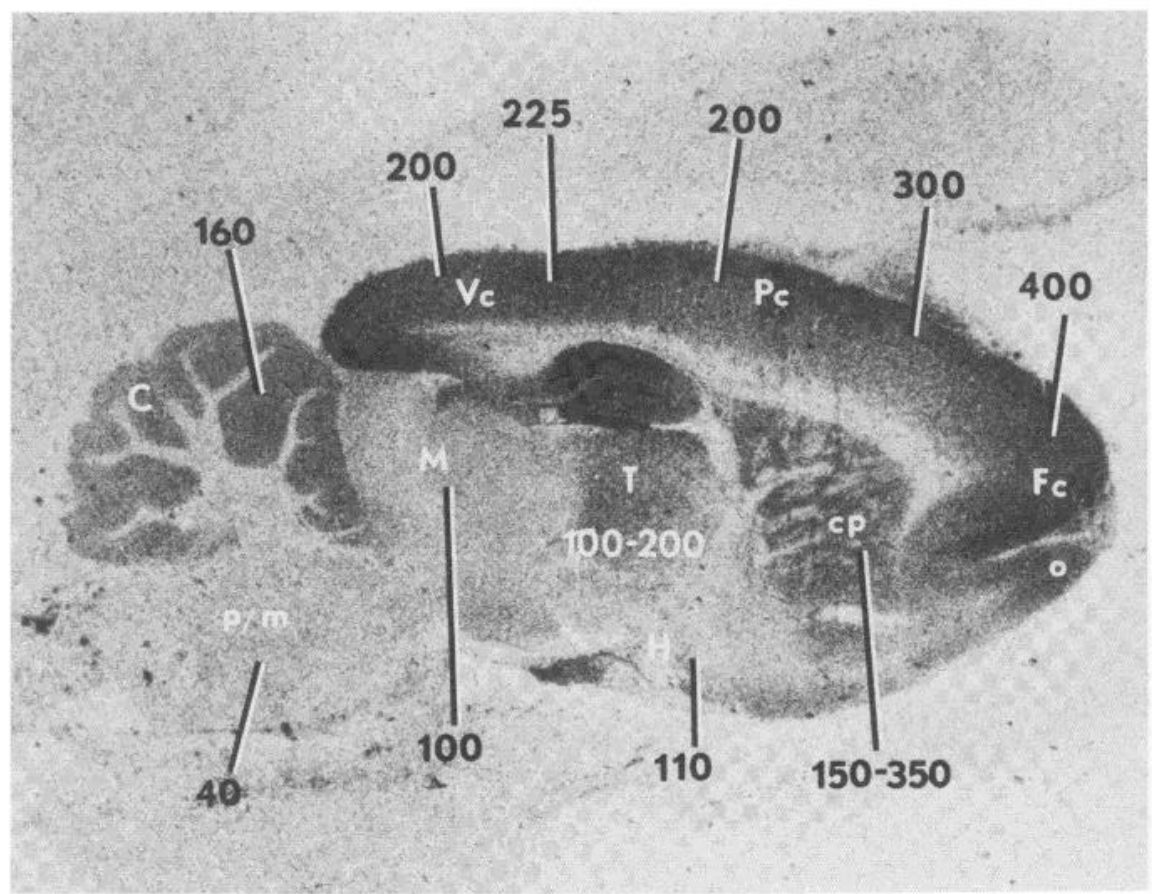

Figure 3. Summary of the distribution of $\left[{ }^{3} \mathrm{H}\right]$ glutamate binding to rat brain frozen sections. This autoradiogram in sagittal section depicts the general distribution of glutamate receptors in various anatomical regions. Rough averages of the level of binding in femtomoles per milligram of protein are indicated for some structures. Note the gradient of binding in the cortex. Rostral areas are high; medial areas are lower, than somewhat high again just anterior to the visual cortex. $C$, cerebellum; $c p$, caudate putamen; $F c$, frontal cortex; $H$, hypothalamus; $M$, midbrain; $O$, olfactory bulb; $P c$, parietal cortex; $p / m$, pons/ medulla; $T$, thalamus; $V c$, visual cortex.

caudate appeared to be more densely labeled than the dorsal two-thirds; and as with cortex, rostral caudate was more darkly labeled than caudal portions. At a level corresponding to PW11 (Fig. $4 B$ ), ventral caudate measured $384 \mathrm{fmol} / \mathrm{mg}$ of protein; at PW14 it was 247 , and at PW16 it was down to $191 \mathrm{fmol} / \mathrm{mg}$ of protein. Likewise, dorsal caudate for these same three coronal levels measured 297, 161, and $158 \mathrm{fmol} / \mathrm{mg}$ of protein, respectively. Note that at each level the ratio of binding in ventral caudate to binding in dorsal caudate remains roughly the same (about 1.2 to 1.5:1). As with area 2, binding in the most caudal sections (PW17 and PW18; Fig. 4C) of both dorsal and ventral caudate was higher than in the intermediate portions (e.g., PW14 to PW16) but not as high as in the most rostral portions (PW11). The adjacent globus pallidus was one of the more lightly labeled structures in the brain, but the large amount of white matter in this structure may cause significant quench of tritium emissions (Alexander et al., 1981; T. C. Rainbow, A. Biegon, and D. Berck, submitted for publication), making it

Figure 4. Anatomical distribution of $\left[{ }^{3} \mathrm{H}\right]$ glutamate binding to rat brain frozen sections. As detailed in the text, $32-\mu \mathrm{m}$ thick sections were pre-incubated in cold Tris- $\mathrm{HCl}$ buffer, then incubated at room temperature for $1 \mathrm{hr}$ with $300 \mathrm{nM}\left[{ }^{3} \mathrm{H}\right]$ glutamate. After rapid drying, the slides were apposed to LKB Ultrofilm for 2 months. Nonspecific binding was defined as the labeling in the presence of 1 mM L-glutamate and corresponded to labeling over white matter. A, Section through the rostral forebrain corresponding to Paxinos and Watson's (1982) Figure 6. High levels of binding are seen throughout the rostral forebrain, including frontal and olfactory cortex. $A O N$, anterior olfactory nucleus; $F r$, frontal cortex. B, Section through the anterior caudate corresponding to Paxinos and Watson's (1982) Figure 11. Anterior caudate is also heavily labeled by $\left[{ }^{3} \mathrm{H}\right]$ glutamate. Note that the more ventral regions of the caudate appear darker than more dorsal regions. This may be due to the relative amounts of white matter. $A C g$, anterior cingulate gyrus; $c p$, caudate putamen; $P O$, primary olfactory cortex. $C$, Section through the level of the ventral hippocampal commissure corresponding to Paxinos and Watson's (1982) Figure 17. The hypothalamic structures show moderate levels of binding. The globus pallidus is very light. The interior layers of the cortex appear lighter here than in more anterior sections. $A H$, anterior hypothalamus; $A V$, anteroventral nucleus of thalamus; $g p$, globus pallidus. $D$, Section through the anterior hypothalamus corresponding to Paxinos and Watson's (1982) Figure 18. Heavy labeling is still seen in the outer layers of cortex. Also heavily labeled is the dentate molecular layer. $D G$, dentate gyrus; $g p$, globus pallidus; $P a S S$, parietal cortex somatosensory area; $V L$, ventrolateral nucleus of the thalamus. $E$, Section through the dorsal hippocampus corresponding to Paxinos and Watson's (1982) Figure 20. High levels of binding are seen in the proximal dendritic fields of CA1, with moderate binding in the distal dendrites which receive the perforant path projection. CA3 is generally less heavily labeled. Moderate levels of binding occur in the thalamus, but several nuclei are clearly discernible. The amygdala contains moderate to high levels of binding. amy, amygdala; $D G$, dentate gyrus; $C A 3$, regio inferior subfield of hippocampus; $M D$, mediodorsal nucleus of the thalamus. $F$, Section through the level of the posterior commissure corresponding to Paxinos and Watson's (1982) Figure 24. Note that the high binding seen in CA1 extends into the subiculum. The central gray is more heavily labeled than its surround. The low-moderate to low levels of binding in the reticular formation extend caudally from here. $C G$, central gray; $D L G$, dorsal lateral geniculate; $M G$, medial geniculate; $S$, subiculum. $G$, Section through the mesencephalon corresponding to Paxinos and Watson's (1982) Figure 28. The superficial layer of the superior colliculus is darker than the deeper layers. The interpeduncular nucleus appears slightly darker than its surrounding regions. $C G$, central gray; $D p M e$, deep mesencephalic nucleus; $I P$, interpeduncular nucleus; $S C$, superior colliculus. $H$, Section through the cerebellum corresponding to Paxinos and Watson's (1982) Figure 39. Cerebellum shows rather uniform labeling throughout the cortical layers. The medulla is typically very light, especially in the nucleus of the spinal trigeminal tract (not pictured). $c$ ctx, cerebellar cortex; PCRt, parvocellular reticular formation; $4 V$, fourth ventricle. 


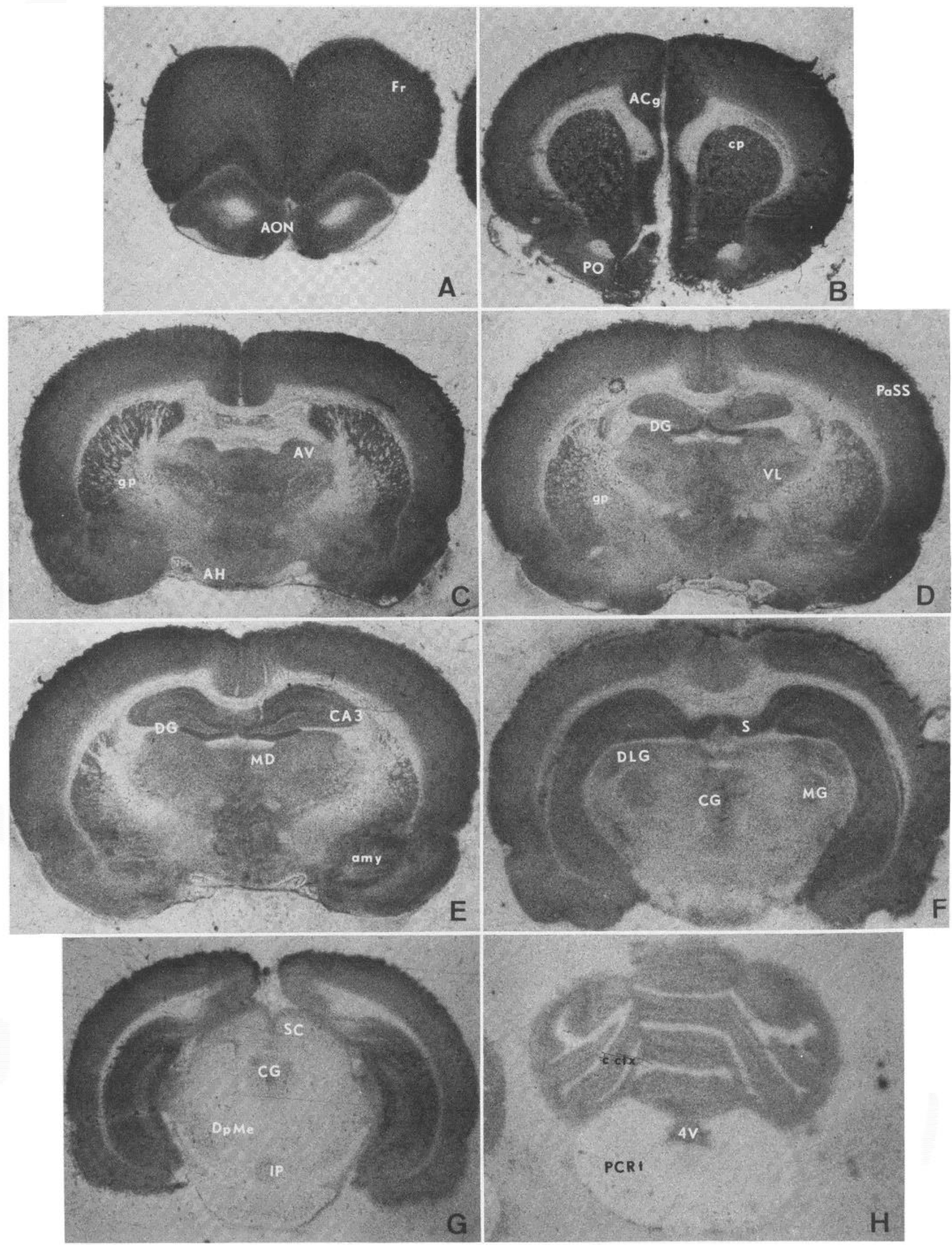


difficult to determine the actual concentration of $\left[{ }^{3} \mathrm{H}\right]$ glutamate binding.

Other telencephalic areas that showed high levels of $\left[{ }^{3} \mathrm{H}\right]$ glutamate binding included olfactory structures, such as the anterior olfactory nucleus, olfactory tubercle, and pyriform cortex (Table II; Fig. 4, $A$ and $B$ ). Again, these were darker in rostral portions ( 300 to $360 \mathrm{fmol} / \mathrm{mg}$ of protein) than in more caudal portions (190 to $240 \mathrm{fmol} / \mathrm{mg}$ of protein). Claustrum and rostral cingulate cortex showed very high binding ( 345 and $366 \mathrm{fmol} / \mathrm{mg}$ ); visual cortex (areas 17 and 18) was relatively light (177 fmol/mg of protein). Limbic structures, such as portions of the hippocampus, septum, and amygdala, were heavily labeled (Fig. 4, $C$ to $F$ ). Dentate gyrus, CA1, and subiculum ( 220 to $250 \mathrm{fmol} / \mathrm{mg}$ ) were noticeably darker than CA3 (150 to $180 \mathrm{fmol} / \mathrm{mg}$ ). CA2 and CA4 were intermediate. Lateral septum $(304 \mathrm{fmol} / \mathrm{mg}$ of in rostral forebrain and 149 $\mathrm{fmol} / \mathrm{mg}$ in medial forebrain) was more heavily labeled than medial septum ( $232 \mathrm{fmol} / \mathrm{mg}$ in rostral forebrain and $84 \mathrm{fmol} /$ $\mathrm{mg}$ in medial forebrain), and both structures were more than twice as dark in rostral sections as in caudal sections. Of amygdaloid nuclei, the posteriomedial cortical nucleus was the most densely labeled ( $236 \mathrm{fmol} / \mathrm{mg}$ of protein).

Closer examination of the hippocampus reveals distinct laminar patterns of $\left[{ }^{3} \mathrm{H}\right]$ glutamate binding (Fig. 5). Binding appears very high in the dentate gyrus molecular layer, but especially in the inner two-thirds. The outer third, closest to the hippocampal fissure, appears noticeably lighter. Likewise, the more distal portion of the CA1 apical dendritic field (stratum lacunosum-moleculare, which is also adjacent to the fissure) is less densely labeled than the more proximal portion (stratum radiatum). As indicated above, stratum radiatum of CA3 (182 fmol/mg of protein) has significantly less $\left[{ }^{3} \mathrm{H}\right]$ glutamate binding than stratum radiatum of CA1 (254 fmol/mg). Stratum oriens is more lightly labeled than stratum radiatum in both regio superior and regio inferior and, as with stratum radiatum, CA1 ( $221 \mathrm{fmol} / \mathrm{mg})$ is substantially darker than CA3 $(154 \mathrm{fmol} / \mathrm{mg})$. CA2, a relatively small area in the rat, also shows more binding in stratum radiatum than in stratum oriens ( $223 \mathrm{fmol} / \mathrm{mg}$ and $190 \mathrm{fmol} / \mathrm{mg}$, respectively), and both strata show values intermediate to the corresponding strata in CA1 and CA3. Not detectable in our densitometric analysis, due to limitations in resolving power of the photocell, is the slightly greater degree of binding in the most proximal portion of the CA3 apical dendritic field known as stratum lucidum (indicated between the arrowheads in Fig. 5).

Diencephalic structures showed moderate to low amounts of binding, with clear differences among the various nuclei (Table II; Fig. $4, C$ to $E$ ). Among thalamic structures, mediodorsal nucleus had the highest amount of glutamate receptors (199 and $178 \mathrm{fmol} / \mathrm{mg}$ of protein), while the ventrolateral nucleus had the least $(101 \mathrm{fmol} / \mathrm{mg}$ of protein). In the hypothalamus, the anterior nucleus was the densest area of glutamate binding (133 fmol/mg of protein), and lateral preoptic nucleus was the lightest ( $43 \mathrm{fmol} / \mathrm{mg}$ of protein).

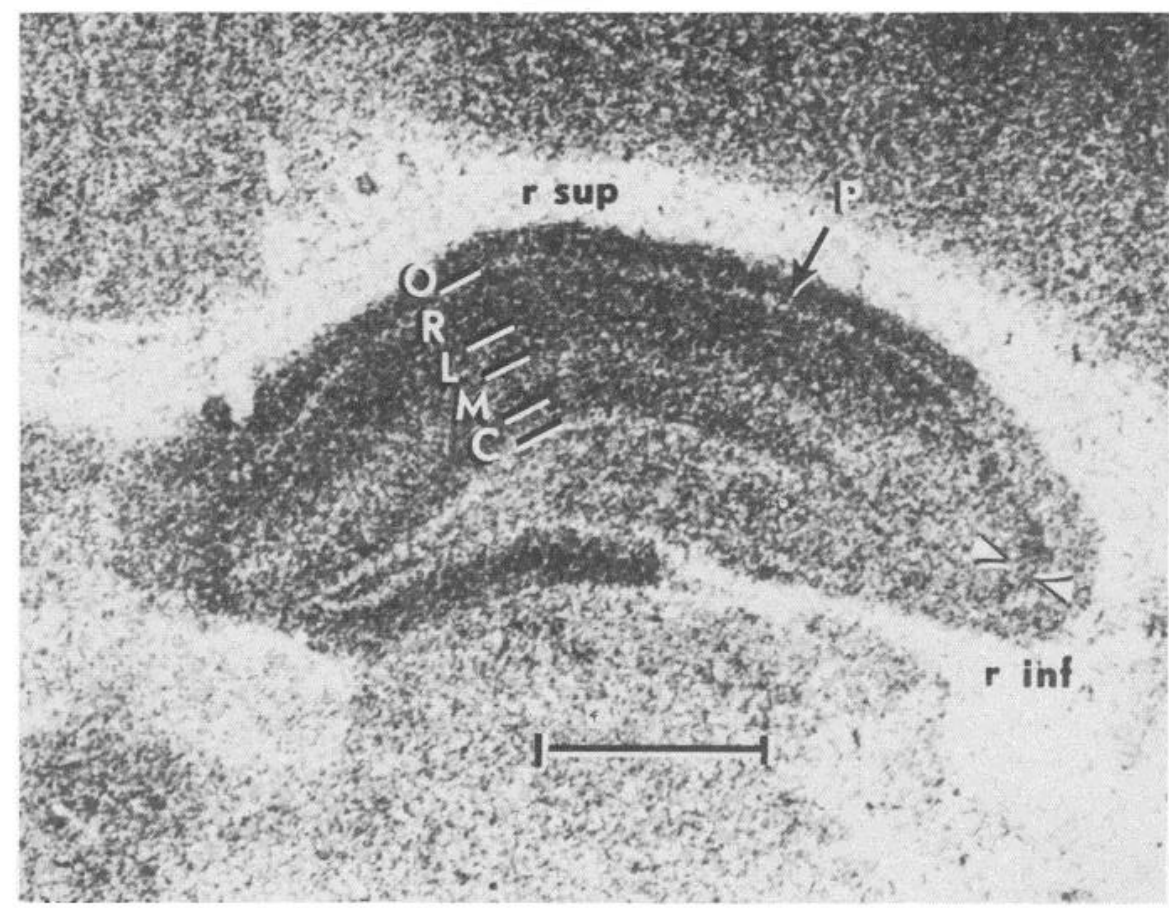

Figure 5. Detailed view of $\left[{ }^{3} \mathrm{H}\right]$ glutamate binding in the hippocampal formation. The LKB autoradiogram was prepared as described above in Figure 4. The major cell layers are visible as thin lines of relatively light binding; the arrow labeled $P$ points to the pyramidal cell layer of regio superior ( $r$ sup $). r$ inf refers to regio inferior, which includes the stratum lucidum of CA3 (demarcated by the two arrowheads). Stratum lucidum appears slightly more heavily labeled than the adjacent stratum radiatum or stratum oriens of CA3. These latter two regions are much less heavily labeled than the corresponding regions in CA1. Like the outer third of the dentate molecular layer, the most distal dendritic layer of CA1 (stratum lacunosum-moleculare) is lighter than layers immediately adjacent to them in the same subfield. Both stratum lacunosum-moleculare and the outer third of the dentate molecular layer are targets of the lateral perforant path. Lines demarcate the borders between various strata in regio superior and dentate molecular layer. $C$, commissural/ associational terminal field (inner one-third of dentate molecular layer); $L$, stratum lacunosum-moleculare; $M$, outer two-thirds of dentate molecular layer; $O$, stratum oriens; $R$ stratum radiatum. Calibration bar: $1 \mathrm{~mm}$. 
Midbrain/pontine areas exhibited moderate to low levels of $\left[{ }^{3} \mathrm{H}\right]$ glutamate binding (Table II; Figs. 3 and $4, F$ and $G$ ). The interpeduncular nucleus was the most densely labeled structure in this area ( $192 \mathrm{fmol} / \mathrm{mg}$ of protein), followed by the central gray at $138 \mathrm{fmol} / \mathrm{mg}$ of protein. The superficial layer of the superior colliculus $(124 \mathrm{fmol} / \mathrm{mg}$ ) was substantially darker than deeper layers $(<80 \mathrm{fmol} / \mathrm{mg})$.

Cerebellar cortex had moderate levels of specific binding in gray matter regions (Figs. 3 and $4 H$ ). The molecular layer (165 $\mathrm{fmol} / \mathrm{mg}$ of protein) was not significantly darker than the Purkinje and granule cell layers ( $160 \mathrm{fmol} / \mathrm{mg}$ of protein). The medulla and associated nuclei (Figs. 3 and $4 H$ ) were uniformly light except for the dorsal cochlear nucleus, which showed a fairly high level of binding at $197 \mathrm{fmol} / \mathrm{mg}$ of protein (Table II). The spinal trigeminal nucleus gave the lowest level of $\left[{ }^{3} \mathrm{H}\right]$ glutamate binding anywhere measured, with $29 \mathrm{fmol} / \mathrm{mg}$ of protein.

\section{Discussion}

The sodium-independent $\left[{ }^{3} \mathrm{H}\right]$ glutamate binding described here possesses many properties which suggest a relationship between it and the synaptic physiology of glutamate neuroexcitation. First, it is found throughout the brain but is distributed nonuniformly. No structures, save perhaps white matter areas which cannot be measured quantitatively with our tritium standards (Alexander et al., 1981; T. C. Rainbow, A. Biegon, and D. Berck, submitted for publication), were shown to have no specific glutamate binding. It is very difficult to find CNS neurons which do not respond to application of exogenous glutamate (Watkins and Evans, 1981), and the ubiquitous distribution of $\left[{ }^{3} \mathrm{H}\right]$ glutamate binding is consistent with such electrophysiological data. Furthermore, structures which have long been viewed as major glutamatergic targets, such as striatum, cortex, dorsal cochlear nucleus, cerebellum, and hippocampus, have the highest levels of binding.

Corticofugal and cortical association pathways are strong candidates for using glutamate or a glutamate-like compound as neurotransmitter. The cortico-striate pathway is one such putative glutamatergic pathway. This assertion has come from a variety of lesion experiments demonstrating that levels of glutamate (Fonnum et al., 1981), high affinity glutamate uptake (Divac et al., 1977), and sodium-dependent binding of glutamate (Vincent and McGeer, 1980) diminish substantially upon complete or partial decortication. The high levels of sodiumindependent binding we see in caudate are consistent with this structure being a major target of glutamate terminals. Likewise, it has been suggested that cortico-cortico pathways use a glutamate-like substance as transmitter (Fonnum and MaltheSorenssen, 1981). The extremely high density of glutamate binding in all cortical regions underscores this possibility. By far the areas densest in glutamate binding are the olfactory and associational areas of rat telencephalon. It is unclear why these areas should have a greater density of glutamate receptors than nearby sensory areas of cortex. Perhaps this phenomenon we observe is consistent with a recent theory of the role of glutamate receptors in an olfactory and associational memory storage process that may be unique to mammalian brain (Lynch and Baudry, 1984). These investigators suggest that mammalian telencephalon may have evolved a specific mechanism for memory storage which involves increases in glutamate receptors and which is not found in nontelencephalic structures. There is evidence that changes in glutamate receptor number accompany certain forms of learning in the rat (Lynch and Baudry, 1984) and rabbit (Thompson et al., 1983).

The densest labeling within a cortical area occurs in the superficial layers. Labeling is heaviest in layers I and II, tapering off in layers III and IV to become about $25 \%$ lighter in the inner layers $V$ and VI. If these binding sites represent synaptic glutamate receptors, then it makes sense, perhaps, that they are to be found concentrated in areas which are dense in synaptic contacts, such as the cortical molecular layer (layer I), and less concentrated in areas rich in cell bodies, such as layer $\mathrm{V}$.

There is much evidence that the dorsal cochlear nucleus receives glutamatergic input from the cochlea via the auditory nerve (Wenthold, 1981). The fact that the highest level of $\left[{ }^{3} \mathrm{H}\right]$ glutamate binding in the caudal brainstem occurs in the dorsal cochlear nucleus supports the proposed role of glutamate neurotransmission in this sensory relay. In addition, this observation illustrates the advantage of using autoradiographic methods to study neurotransmitter receptor binding. Available dissection techniques would require many animals in order to generate enough tissue for conventional membrane preparation and binding assay on such a circumscribed region.

The binding of $\left[{ }^{3} \mathrm{H}\right]$ glutamate in the cerebellar cortex was less than might be expected given the many lines of evidence pointing to glutamate as the transmitter of the granule cell parallel fibers (Young et al., 1974; Fonnum and Malthe-Sorenssen, 1981). However, recent reports indicate that another endogenous amino acid, cysteine sulfinic acid, has specific binding sites highly concentrated in cerebellum (Recasens et al., 1982) and that these sites may be responsible for much of the acidic amino acid excitation occurring in this structure. The moderate levels of $\left[{ }^{3} \mathrm{H}\right]$ glutamate binding we see in cerebellum are in marked contrast to the high levels reported by others using synaptic membrane preparations (Baudry and Lynch, 1981). These authors reported binding to cerebellar membranes to be twice as great as binding to hippocampal membranes. The reason for this discrepancy is unclear; however, it is very difficult to compare results obtained with such widely different assay methods. Unlike Greenamyre et al. (1983) we saw no significant difference in $\left[{ }^{3} \mathrm{H}\right]$ glutamate binding in the various layers of cerebellar gray matter. The inclusion of $2.5 \mathrm{mM} \mathrm{CaCl}{ }_{2}$ in the assay buffer by these authors may account for this difference.

The high amounts of $\left[{ }^{3} \mathrm{H}\right]$ glutamate binding in the hippocampal formation are in agreement with findings from studies of synaptic membrane preparations (Baudry and Lynch, 1981; Werling and Nadler, 1982; Fagg et al., 1983) and of the proposed role of glutamate excitation in this brain structure. All of the major intrinsic pathways of the hippocampus and its major input, the perforant path, at one time or another have been proposed to be glutamatergic in nature (Fonnum and MaltheSorenssen, 1981; Storm-Mathisen, 1981; Yamamoto and Sawada, 1982). Accordingly, we observe high levels of glutamate binding in target zones of each of these pathways. The heaviest binding is found in subiculum, in stratum radiatum and stratum oriens of $\mathrm{CA} 1$, and in the inner two-thirds of the dentate molecular layer (Fig. 5). $\left[{ }^{3} \mathrm{H}\right]$ Glutamate binding in the hippocampus appears to be largely confined to axons, terminals, and/ or dendritic processes since neither the pyramidal or granule cell layers themselves are very heavily labeled. This is in contrast to the cerebellum where the cell layers appear as densely labeled as the molecular layer. The cerebellar granule cells probably receive excitatory input via the climbing fibers and mossy fibers (Rea et al., 1980; Foster and Roberts, 1983; Freeman et al., 1983; Toggenburger et al., 1983). In the hippocampus, however, the somata themselves are not targets of the excitatory intrinsic connections or perforant path terminals. Instead they are the targets of many inhibitory interneuron populations which probably release GABA as their transmitter (Storm-Mathisen, 1977).

Within the hippocampal formation, the subiculum receives a substantial input from the ipsilateral CA1 pyramidal cells (Andersen et al., 1973; Hjorth-Simonsen, 1973) and serves as the major output station from the hippocampus (Swanson and 
Cowan, 1977; Meibach and Siegel, 1977). Stratum radiatum of $\mathrm{CAl}$ receives the vast majority of its input from ipsilateral and contralateral regio inferior pyramidal cells via the Schaffer collateral/commissural projections, and stratum oriens of $\mathrm{CA} 1$ gets mostly commissural input from regio inferior (Andersen, 1975). The high amounts of glutamate receptor in regio superior and subiculum support the suggestion that a glutamate-like compound is the neurotransmitter of $\mathrm{CA} 1$ and CA3 pyramidal cells (Storm-Mathisen, 1981).

The inner two-thirds of the dentate molecular layer receive input from two sources. The innermost third (closest to the granule cell layer) receives commissural and associational fibers from regio inferior pyramidal cells. The middle one-third receives projections from the medial perforant path, which originates in the medial entorhinal cortex. The terminal fields of these two projections are strictly segregated in their target zone on the dentate granule cells (Blackstad, 1956). Their proximity to glutamate receptors is additional evidence that these two pathways may use glutamate as a neurotransmitter. The outermost third of dentate granule cell dendrites receives lateral perforant path terminals from the lateral entorhinal cortex. This pathway, too, is strictly segregated in the dendritic field of the dentate gyrus (Hjorth-Simonsen and Jeune, 1972; Steward and Scoville, 1976). This outer third is less heavily labeled by $\left[{ }^{3} \mathrm{H}\right]$ glutamate than the inner two-thirds. Interestingly, the part of hippocampus proper that also receives lateral perforant path projections, stratum lacunosum-moleculare of CA1, also is less heavily labeled than the adjacent stratum radiatum. This heterogeneity in glutamate binding within a dendritic field could be due to a gradient in the density of synapses along the length of the dendritic arbor. Alternatively, these sparse regions could be occupied by another population of receptors not detected by our methods. In support of this idea, Monaghan et al. (1983) recently reported that at least four distinct classes of glutamate receptors can be localized within the hippocampus by autoradiography. Since none of their labeling conditions for visualizing receptor subtypes precisely correspond to our own, it is difficult to assess the degree to which our results coincide, a major procedural difference being the inclusion of chloride in our assay buffer versus either the absence of chloride or the simultaneous inclusion of both calcium and chloride in theirs. However, it would appear from their results that $\mathrm{CaCl}_{2}$ induces an increase in glutamate receptors along the target zone of the perforant path. It is interesting to speculate that these receptors are induced by calcium, since the pattern of labeling we see in the presence of chloride alone indicates that the anion is not responsible for this effect.

Another part of the hippocampus that is only moderately labeled by $\left[{ }^{3} \mathrm{H}\right]$ glutamate is CA3. Nowhere is CA3 as densely labeled as $\mathrm{CA} 1$; however, the portion of $\mathrm{CA} 3$ that receives the mossy fiber input from the dentate granule cells, the stratum lucidum, is slightly darker than the portion that receives input from elsewhere in hippocampus, stratum radiatum and stratum oriens. The stratum lucidum has been shown to contain a high density of the kainic acid type of receptors (Monaghan and Cotman, 1982; Unnerstall and Wamsley, 1983). Since kainate receptors have a fairly high affinity for glutamate as well as for kainate (Simon et al., 1976), it is conceivable that a portion of the binding we see in stratum lucidum may be to the kainate subclass of glutamate receptors.

It is important to note that the sodium-independent binding site described here for $\left[{ }^{3} \mathrm{H}\right]$ glutamate is distinct from the sodium-dependent binding site for $\left[{ }^{3} \mathrm{H}\right]-\mathrm{D}$-aspartate that we have localized by quantitative autoradiography (Parsons and Rainbow, 1983). The D-aspartate site is presumably some aspect of the presynaptic uptake site for L-glutamate and related excitatory amino acids such as $\mathbf{L}$-asparate and $\mathbf{L}$-cysteine sulfinate. The specificity of this site for inhibition by excitatory amino acids is different than the pharmacological specificity of $\left[{ }^{3} \mathrm{H}\right]$ glutamate binding to frozen sections. Neither quisqualate nor ibotenate competed significantly for $\left[{ }^{3} \mathrm{H}\right]-\mathrm{D}$-aspartate binding (Parsons and Rainbow, 1983), while both compounds were strong competitors of $\left[{ }^{3} \mathrm{H}\right]$ glutamate binding (Table I). The anatomical distribution of $\left[{ }^{3} \mathrm{H}\right]-\mathrm{D}$-aspartate-binding sites was generally similar to the location of sodium-independent $\left[{ }^{3} \mathrm{H}\right]$ glutamate-binding sites, suggesting that glutamatergic presynaptic terminals may be closely associated with postsynaptic glutamate receptors. This is in contrast with the poor overlap in location of some neurotransmitter receptors and their presynaptic neurotransmitters (Kuhar, 1981; Biegon et al., 1982). A discrepancy between $\left[{ }^{3} \mathrm{H}\right]$-D-aspartate and $\left[{ }^{3} \mathrm{H}\right]$ glutamate binding occurs in the cerebellum, which, relative to other brain regions, is much more concentrated in $\mathrm{D}$-aspartate sites than it is in L-glutamate receptors (Parsons and Rainbow, 1983; B. Parsons and 'T. C. Rainbow, unpublished data). 'This might result from the binding of $\left[{ }^{3} \mathrm{H}\right]$-D-aspartate to sodium-dependent cysteine sulfinic acid sites, which are highly concentrated in the cerebellum (Parsons and Rainbow, 1984).

The characteristics of $\left[{ }^{3} \mathrm{H}\right]$ glutamate binding to frozen sections indicate that we are labeling at least two populations of sodium-independent glutamate sites with different affinity for quisqualic acid and different sensitivity to chloride. This result is in agreement with reports by Nadler and colleagues, who define a chloride-dependent "Glu A" site as one having a high affinity for quisqualate and a chloride-independent "Glu B" site as one with low affinity for quisqualate (Werling and Nadler, 1983; Werling et al., 1983). It is possible that the biphasic quisqualate competition curve we obtain with frozen sections represents binding to the Glu A and Glu B sites; however, more studies are necessary before this can be stated with certainty. Werling et al. (1983) found that freezing and thawing their homogenates has the effect of drastically reducing Glu A binding and enhancing Glu B binding. It is not known whether the freezing and thawing procedures involved in the preparation of cryostat sections for autoradiography would have the same effect on integral membrane proteins as do the freezing and thawing of broken membranes. Another binding site having a high affinity for quisqualic acid has recently been described (Honore et al., 1982). This site is labeled by $\left[{ }^{3} \mathrm{H}\right]$ AMPA and appears to be distinct from the Glu A and Glu B sites. We have mapped the $\left[{ }^{3} \mathrm{H}\right]$ AMPA-binding site by procedures similar to those described here and found it to have distribution that is distinct from $\left[{ }^{3} \mathrm{H}\right]$ glutamate binding (Rainbow et al., 1984). The AMPA-binding site is not dependent on chloride ion; therefore, the high affinity portion of the quisqualate competition curve in the absence of chloride may be attributable to the AMPA-binding site. In the presence of this ion, glutamate binding to the AMPA site may be "masked" by the presence of a site like Glu A. This could explain why scintillation counting experiments showed that AMPA did not compete significantly for $\left[{ }^{3} \mathrm{H}\right]$ glutamate binding when chloride was present (Table I). Thus, $\left[{ }^{3} \mathrm{H}\right]$ glutamate autoradiography on frozen sections may be visualizing three separate populations of glutamate-binding sites: a chloride-dependent Glu A site, a chloride-independent Glu B site, and a chloride-independent AMPA site.

Although more work will be needed to establish whether $\left[{ }^{3} \mathrm{H}\right]$ glutamate binding to frozen sections corresponds to Glu A, Glu $\mathrm{B}$, and AMPA subclasses, it appears that this binding represents physiologically relevant glutamate interaction sites which have many of the properties expected of postsynaptic receptors for excitatory neurotransmission at glutamatergic pathways. It is known that both glutamate and aspartate have mixed actions on the electrophysiological responses of CNS neurons and that specificities of these responses do not correlate well with receptor binding data (Watkins and Evans, 1981). The presence of 
multiple receptor subtypes probably contributes to these discrepancies. Quantitative autoradiographic analysis of multiple glutamate receptor subtypes and their relative distributions will help to alleviate this problem. By making possible a level of anatomical resolution unattainable with previous methods, such studies are likely to provide important information regarding the nature of glutamatergic function in mammalian brain.

\section{References}

Alexander, G. M., R. J. Schwartzman, R. D. Bell, and A. Renthal (1981) Quantitative measurement of local cerebral metabolic rate for glucose utilizing tritiated 2-deoxyglucose. Brain Res. 223: 59-67.

Andersen, P. (1975) Organization of hippocampal neurons and their interconnections. In The Hippocampus. Vol. 1: Structure and Development, R. L. Isaacson and K. H. Pribram, eds., pp 155-175, Plenum Press, New York.

Andersen, P., B. H. Bland, and J. D. Dudar (1973) Organization of the hippocampal output. Exp. Brain Res. 17: 152-168.

Baudry, M., and G. Lynch (1981) Characterization of two $\left[{ }^{3} \mathrm{H}\right]$-glutamate binding sites in rat hippocampal membranes. J. Neurochem. 36: $811-820$.

Biegon, A., T. C. Rainbow, and B. S. McEwen (1982) Quantitative autoradiography of serotonin $n_{1}$ receptors in the rat brain. Brain Res. 242: $197-204$

Biziere, K., H. Thompson, and J. T. Coyle (1980) Characterization of specific, high-affinity binding sites for $\mathrm{L}-\left[{ }^{3} \mathrm{H}\right]$ glutamatic acid in rat brain membranes. Brain Res. 183: 421-433.

Blackstad, T. W. (1956) Commissural connections of the hippocampal region in the rat with specific references to the mode of termination. J. Comp. Neurol. 105: 417-537.

Cotman, C. W., and A. Hamberger (1977) Glutamate as a CNS neurotransmitter: Properties of release, inactivation and biosynthesis. In Amino Acids as Chemical Transmitters, F. Fonnum, ed., pp. 379-412, Plenum Press, New York.

Curtis, D. R., and J. R. Watkins (1960) The excitation and depression of spinal neurones by structurally related amino acids. J. Neurochem. 6: $117-141$.

Davies, J., and J. C. Watkins (1983) Role of excitatory amino acid receptors in mono- and polysynaptic excitation in the cat spinal cord. Exp. Brain Res. 49: 280-290.

Dingledine, R. (1983) Excitatory amino acids: Models of action on hippocampal pyramidal cells. Fed. Proc. 42: 2881-2885.

Divac, I., F. Fonnum, and J. Storm-Mathisen (1977) High-affinity uptake of glutamate in terminals of corticostriatal axons. Nature 266: 377-378.

Fagg, G. E., A. C. Foster, E. E. Mena, and C. W. Cotman (1983) Chloride and calcium ions separate L-glutamate receptor populations in synaptic membranes. Eur. J. Pharmacol. 88: 105-110.

Fonnum, F., and D. Malthe-Sorenssen (1981) Localization of glutamate neurons. In Glutamate: Transmitter in the Central Nervous System, P. J. Roberts, J. Storm-Mathisen, and G. A. R. Johnston, eds., pp. 205 222, John Wiley \& Sons, Inc., New York.

Fonnum, F., J. Storm-Mathisen, and I. Divac (1981) Biochemical evidence for glutamate as a neurotransmitter in corticostriatal and corticothalamic fibers in rat brain. Neuroscience 6: 863-874.

Foster, A. C., and P. J. Roberts (1978) High-affinity L- $\left[{ }^{3} \mathrm{H}\right]$ glutamate binding to postsynaptic receptor sites on rat cerebellar membranes. J. Neurochem. 31: 1467-1477.

Foster, G. A., and P. J. Roberts (1983) Neurochemical and pharmacological correlates of inferior olive destruction in the rat: Attenuation of the events mediated by an endogenous glutamate-like substance. Neuroscience 8: 277-284.

Freeman, M. E., J. D. Lane, and J. E. Smith (1983) Turnover rates of amino acid neurotransmitters in regions of rat cerebellum. J. Neurochem. 40: 1441-1447.

Greenamyre, J. T., A. B. Young, and J. B. Penney, Jr. (1983) Quantitative autoradiography of $\mathbf{L}-\left[{ }^{3} \mathrm{H}\right]$ glutamate binding to rat brain. Neurosci. Lett. 37: 155-160.

Halpain, S., B. Parsons, and T. C. Rainbow (1983) Tritium-film autoradiography of sodium-independent glutamate binding sites in rat brain. Eur. J. Pharmacol. 86: 313-314.

Hjorth-Simonsen, A. (1973) Some intrinsic connections of the hippo- campus in the rat: An experimental analysis. J. Comp. Neurol. 147: $145-161$.

Hjorth-Simonsen, A., and B. Jeune (1972) Origin and determination of the hippocampal perforent path in the rat studied by silver impregnation. J. Comp. Neurol. 144: 215-232.

Honore, T., J. Laurisden, and P. Krogsgaard-Larsen (1982) The binding of $\left[{ }^{3} \mathrm{H}\right] \mathrm{AMPA}$, a structural analogue of glutamic acid, to rat brain membranes. J. Neurochem. 38: 173-178.

Klotz, I. M. (1982) Numbers of receptor sites from Scatchard graphs: Facts and fantasies. Science 217: 1247-1249.

Krieg, W. J. S. (1946) Connections of the cerebral cortex. I. The albino rat. A. Topography of the cortical areas. J. Comp. Neurol. 84: 221276.

Krogsgaard-Larsen, P., T. Honore, J. J. Hansen, D. R. Curtis, and D. Lodge (1980) New class of glutamate agonist structurally related to ibotenic acid. Nature 284: 64-66.

Kuhar, M. (1981) Autoradiographic localization of drug and neurotransmitter receptors in the brain. Trends Neurosci. 4: 60-64.

Logan, W. J., and S. H. Snyder (1972) High affinity uptake systems for glycine, glutamate, and aspartic acids in synaptosomes of rat central nervous tissues. Brain Res. 42: 413-431.

Lynch, G., and M. Baudry (1984) The biochemestry of memory: A new and specific hypothesis. Science 224: 1057-1063.

Meibach, R. C., and A. Siegel (1977) Efferent connections of the hippocampal formation in the rat. Brain Res. 124: 197-244.

Michaelis, E. K., M. L. Michaelis, H. H. Chang, R. D. Grubbs, and D. R. Kuonen (1981) Molecular characteristics of glutamate receptors in the mammalian brain. Mol. Cell. Biochem. 38: 163-179.

Monaghan, D. T., and C. W. Cotman (1982) The distribution of $\left[{ }^{3} \mathrm{H}\right]$ kainic acid binding sites in rat CNS as determined by autoradiography. Brain Res. 252: 91-100.

Monaghan, D. T., V. R. Holets, D. W. Toy, and C. W. Cotman (1983) Anatomical distributions of four pharmacologically distinct $\left[{ }^{3} \mathrm{H}\right] \mathrm{L}-$ glutamate binding sites. Nature 306: 174-178.

Nadler, J. V., K. W. Vaca, W. F. White, G. S. Lynch, and C. W. Cotman (1976) Aspartate and glutamate as possible transmitters of excitatory hippocampal afferents. Nature 260: 538-540.

Pan, H. S., K. A. Frey, A. B. Young, and J. B. Penney, Jr. (1983) Changes in $\left[{ }^{3} \mathrm{H}\right]$ muscimol binding in substantia nigra, entopedunuclar nucleus, globus pallidus, and thalamus after striatal lesions as demonstrated by quantitative receptor autoradiography. J. Neurosci. 3: 1189-1198.

Parsons, B., and T. C. Rainbow (1983) Quantitative autoradiography of sodium-dependent $\left[{ }^{3} \mathrm{H}\right] \mathrm{D}$-aspartate sites in rat brain. Neurosci. Lett. 36: 9-12.

Parsons, B., and T. C. Rainbow (1984) Localization of cysteine sulfinic acid re-uptake sites in rat brain by quantitative autoradiography. Brain Res. 294: 193-197.

Paxinos, G., and C. Watson (1982) The Rat Brain in Stereotaxic Coordinates, Academic Press, Inc., New York.

Quirion, R., R. P. Hammer, Jr., M. Herkenham, and C. B. Pert (1981) Phencyclidine (angel dust)/ $\sigma$ "opiate" receptor: Visualization by tritium-sensitive film. Proc. Natl. Acad. Sci. U. S. A. 78: 5881-5885.

Rainbow, T. C., W. V. Bleisch, A. Biegon, and B. S. McEwen (1982) Quantitative densitometry of neurotransmitter receptors. J. Neurosci. Methods 5: $127-138$.

Rainbow, T. C., C. M. Wieczorek, and S. Halpain (1984) Quantitative autoradiography of binding sites for $\left[{ }^{3} \mathrm{H}\right] \mathrm{AMPA}$, a structural analogue of glutamic acid. Brain Res., in press.

Rea, M. A., W. J. McBride, and B. H. Brode (1980) Regional and synaptosomal levels of amino acid neurotransmitters in the 3-acetylpyridine deafferentated rat cerebellum. J. Neurochem. 34: 11061108.

Recasens, M., V. Varga, D. Nanopoulos, F. Saadoun, G. Vincendon, and J. Benauides (1982) Evidence for cysteine sulfinate as a neurotransmitter. Brain Res. 239: 153-173.

Simon, J. R., J. F. Contrera, and M. J. Kuhar (1976) Binding of $\left[{ }^{3} \mathrm{H}\right]$ kainic acid, an analogue of L-glutamate, to brain membranes. J. Neurochem. 26: 141 147.

Steward, O., and S. A Scoville (1976) Cells of origin of entorhinal afferents to the hippocampus and fascia dentata of the rat. J. Comp. Neurol. 169: 347-370.

Storm-Mathisen, J. (1977) Localization of transmitter candidates in the brain: The hippocampal formation as a model. Prog. Neurobiol. 8: $119-181$. 
Storm-Mathisen, J. (1981) Glutamate in hippocampal pathways. Adv. Biochem. Psychpharmacol. 27: 43-56.

Swanson, L. W., and W. S. M. Cowan (1977) An autoradiographic study of the organization of the efferent connections of the hippocampal formation in the rat. J. Comp. Neurol. 172: 49-84.

Thompson, R. F., L. A. Mamounas, G. Lynch, and M. Baudry (1983) Increased glutamate receptor binding in hippocampus following classical conditioning of the rabbit eyelid response. Soc. Neurosci. Abstr. 9: 830 .

Toggenburger, G., L. Wiklund, H. Henke, and M. Cuenod (1983) Release of endogenous and accumulated exogenous amino acids from slices of normal and climbing fiber-deprived rat cerebellar slices. J. Neurochem. 41: 1606-1613.

Unnerstall, J. R., D. L. Niehoff, M. J. Kuhar, and J. M. Palacios (1982) Quantitative receptor autoradiography using $\left[{ }^{3} \mathrm{H}\right]$ Ultrofilm: Application to multiple benzodiazepine receptors. J. Neurosci. Methods 6 : $59-73$.

Unnerstall, J. R., and J. K. Wamsley (1983) Autoradiographic localization of high-affinity $\left[{ }^{3} \mathrm{H}\right]$ kainic acid binding sites in the rat forebrain. Eur. J. Pharmacol. 86: 361-371.

Vincent, S. R., and E. G. McGeer (1980) A comparison of sodium dependent glutamate binding with high-affinity uptake in rat striatum. Brain Res. 184: 99-108.
Watkins, J. C., and R. H. Evans (1981) Excitatory amino acid neurotransmitters. Annu. Rev. Pharmacol. Toxicol. 21: 165-204.

Wenthold, R. J. (1981) Glutamate and asparatate as neurotransmitters for the auditory nerve. Adv. Biochem. Psychopharmacol. 27: 69-78.

Werling, L. L., K. A. Doman, and J. V. Nadler (1983) L- $\left[{ }^{3}\right.$ H]Glutamate binding to hippocampal synaptic membranes: Two binding sites discriminated by their differing affinities for quisqualate. J. Neurochem. 41: 586-593.

Werling, L. L., and J. V. Nadler (1982) Complex binding of $\left[{ }^{3} \mathrm{H}\right]$ glutamate to hippocampal synaptic membranes in the absence of sodium. J. Neurochem. 38: 1050-1062.

Werling, L. L., and J. V. Nadler (1983) Multiple binding sites for L$\left[{ }^{3} \mathrm{H}\right]$ glutamate on hippocampal synaptic membranes: Effects of calcium and chloride ions. Soc. Neurosci. Abstr. 9: 1186.

Yamamoto, C., and S. Sawada (1982) Sensitivity of hippocampal neurons to glutamic acid and its analogues. Brain Res. 235: 358-362.

Young, A. B., M. L. Oster-Granite, R. M. Herdon, and S. H. Snyder (1974) Glutamic acid: Selective depletion by viral-induced granule cell loss in hamster cerebellum. Brain Res. 73: 1-13.

Young, W. S., III, and M. J. Kuhar (1979) A new method for receptor autoradiography: $\left[{ }^{3} \mathrm{H}\right]$ opioid receptors in rat brain. Brain Res. 179: $255-270$. 